Finally, the fresh-water station should be above all things an experimental one, and in this direction the most valuable results are to be looked for, both from the general scientific and from the technical standpoint. To the scientist, this needs no demonstration; but it is essential that the importance of such work, especially for fish eulture, be more widely understood. The advance in agricultural methods in the United States is unquestionably due in large part to the development of a splendid series of agricultural experiment stations in which agricultural problems have been subjected to intensive experimentation. Contrasted with this, conditions in fish culture present almost the opposite extreme. Fish eggs have been hatched in enormous numbers, but what is known of their subsequent history or what has been done to insure the safe development to maturity of the fish ? Present methods have reached their limit and the subject must be attacked from a different standpoint. Fish culture should receive by the liberality of state and nation the same favors that have been extended to agriculture, the use of permanent and wellequipped experiment stations where trained workers shall devote their time and energy to the solution of its problems. Thoroughness and continuity are essential, for these problems really deal with all conditions of existence in the water. Of what does the food of each fish consist, where is it found and in what amount, how may it be increased and improved; to what extent and how can the number of fish be multiplied, and how far is this profitable; what are the best kinds of fish and what new varieties can be produced? These are a few of the many questions to be solved.

The problems outlined are indeed vast, and yet we may be confident that their solution lies easily within the power of the human intellect, for they are all paralleled in the history of the agricultural develop- ment of the race; and man, relying upon his success in the past, may go forward with supreme confidence to the attainment of their solution in this new field.

HENRY B. W ARD.

ZoOLOGICAL LABORATORY,

The University of Nebraska.

\section{BRUNISSURE OF THE VINE AND OTHER PLANTS.}

Since the publication, in 1892 , of the papers by Viala and Sauvageau describing Brunissure of the Vine and the California Vine disease as due to Plasmodiophora vitis (Viala et Sauv.) and P. californica (Viala et Sauv.) much interest has been manifested in these supposed new parasites. F. Debray and A. Brive in Revue de Viticulture, 1895, claimed to have found the parasite in a large number of plants belonging to numerous families and genera. They made a new genus for the organism calling it Pseudocommis vitis. By far the best work, however, has been done by Viala and Sauvageau. A full discussion of their work with bibliography may be found in 'Les Maladies de la Vigne, par Pierre Viala, Troisième édition 1893, pp. 400-413. Any one who has observed for himself the peculiar structures described would most likely decide at once that they must belong, or be at least closely related, to the genus Plasmodiophora. The peculiar vacuolate plasmodium-like structures may be best studied, following the directions of Viala (in Maladies de la Vigne), by slowly clearing the sections or tissues in dilute eau de javelle. The protoplasm of the host cell is said to be dissolved, while that of the plasmodes remains for a long time unattacked. The plasmodes may then be colored with iodine or other stains, bringing out their structure very sharply. I have recently repeated these experiments very carefully and find everything described by Viala and Sauvageau in Vitis and also as described by 
Debray in other plants. In fact, the phenomena can be produced in all plants so far as I have examined, whether healthy or diseased, especially in cells containing chlorophyll. I obtained the plasmode structures readily in leaves and stems of Vitis, Lilium harrisii, Tobacco, Tomato, Rose and Hyacinth and in Spirogyra cells. If one watches the action of eau de javelle closely under the microscope a slight plasmolysis of the cells is first seen which may increase or afterwards disappear. The chloroplasts swell and become colorless and unite with each other, and usually with the rest of the protein, into an amorphous mass almost transparent. This mass after a time contracts into a single vacuolate plasmodium-like structure or into several such structures in each cell. 'These become highly refractive and remain without much change for several hours or disappear, according to the strength of the reagent. In this stage the plasmodes may be coagulated with alcohol or iodine and stained and permanently mounted in glycerine containing alcohol or iodine. If dilute glycerine or pure water is added before coagulation the plasmode structures swell, lose their high refraction and become amorphous. In coagulation these formations behave like any albuminoid substance. Their formation, however, is entirely different from the separation of active albumen in the cell by the addition of an aqueous solution of caffeine as described by Dr. Loew. This difference will be discussed in a fuller paper now in preparation. The action of the eau de javelle is most likely an oxidation in the presence of an alkali. Changes of the kind described are not produced by a mixture of sodium chloride $5 \%$ and sodium hydrate $1 \%$ or of either of these acting alone. A phenomenon quite similar, however, is produced in the Lily if the tissues are first soaked in peroxide of hydrogen till discolored and sections then mounted in sodium chloride $5 \%$ and sodium hydrate $1 \%$. The cell contents then quickly swell and become amorphous, and highly refractiveplasmode structures separate out. These gradually disappear if not coagulated with iodine or alcohol. In the latter case they behave as do the similar structures produced by the eau de javelle. If the theory is correct that these changes are produced by an oxidation of the chloroplasts and other cell contents in an alkaline medium it explains why such structures, or a reticulate form of them, usually appear in cells which slowly die and become brown around the punctures of aphids in the leaf of the Bermuda lily. Numerous tests made by the writer have shown that plants which react in this manner to aphis punctures contain much larger quantities of oxidizing enzyme than plants which do not so reart. The presence of the substance injected into the wound by the aphis probably causes the neighboring cells to increase still more in oxidizing enzyme until the presence of the latter in excessive quantity destroys or oxidizes the chloroplasts. The cell slowly dies, and the rest of the cell contents may then be attacked. A brownish shrunken amorphous mass is left. On the addition of dilute potassium hydrate or sodium hydrate to sections from such spots the oxidized protoplasm in the cells which have turned brown swells up and becomes a reticulated or vacuolate mass, such as is often obtained with the eau de javelle or the peroxide of hydrogen and sodium hydrate. It is quite likely, therefore, that plasmode structures would be formed by an alkali in any cells that had previously become oxidized either from the presence of oxidizing enzyme in themselves or from any other cause. These observations indicate quite decidedly that the supposed Plasmodiophora vitis or Pseudocommis vitis are nothing but microchemical reactions, brought on by oxidations and the influence of an alkali upon the en- 
tire protein contents of cells, especially upon chloroplasts.

A complete account of the work with illustrations will be published soon.

Albert F. Woods.

Division of Vegetable Physiology

and Pathology, U. S. Dept. Agriculture.

\section{AN AUTOMATIC MERCURY PUMP.}

Although there is nothing especially new in regard to the pump proper, the method of electrical control may be sufficiently novel to warrant a brief description. flask filled with mercury. A tight joint is made between the flask and pump by a rubber stopper. This stopper also serves as a flexible support for the body of the pump. The exhaust tube is sealed into the pump just above the point at which the pump passes into the flask. The arrangement is best shown by the figure.

The tube to be exhausted is attached to the pump, through a drying bulb filled with anhydrous phosphoric acid, by a simple ground joint with a mercury seal. The valve at the top of the pump is ground to

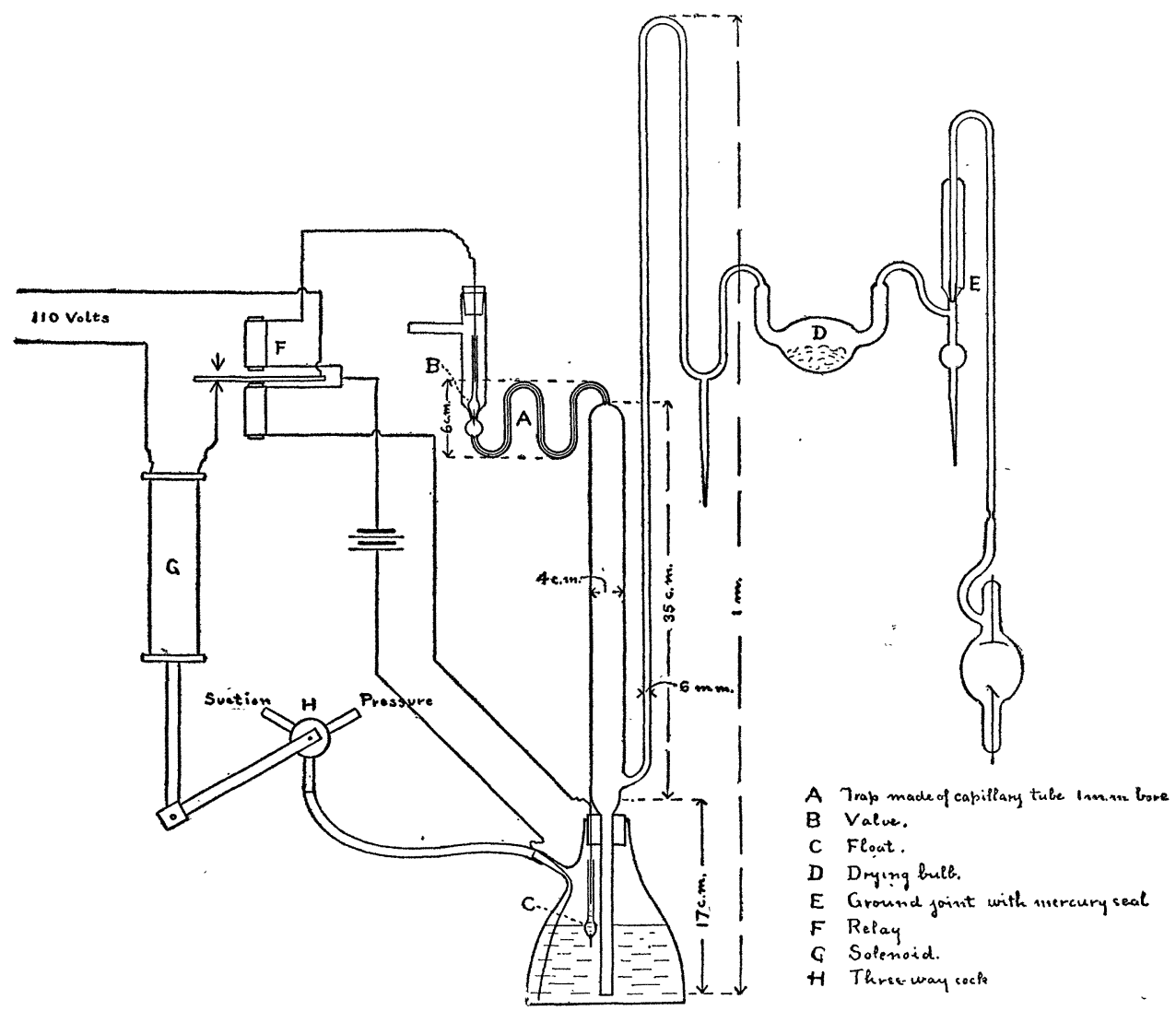

The pump proper is a modification of a common form of Geissler pump. It consists of a long glass tube, about $1 \frac{1}{4}$ inches in diameter, which has a mercury trap and a small glass valve at the top. The bottom of the tube is drawn down and dips into a fit its seat and so weighted by filling with mercury that it closes, leaving sufficient mercury above it to form a tight joint. Dimensions which give very satisfactory results are shown on the figure. Suction is applied permanently to the top of the pump 